\title{
Differences in Depression Level among Rural and Urban Adolescents of Haryana, India
}

\author{
Rupika Chopra* and Sheela Sangwan
}

Department of Human Development and Family Studies, I.C. College of Home Science, CCS Haryana Agricultural University, Hisar (125004), Haryana, India

*Corresponding author

\begin{tabular}{|c|c|}
\hline & A B S T R A C T \\
\hline $\begin{array}{l}\text { Depression, } \\
\text { Negative mood, } \\
\text { Negative self- } \\
\text { esteem, Rural } \\
\text { adolescents, Urban } \\
\text { adolescents and } \\
\text { Ineffectiveness }\end{array}$ & \multirow{3}{*}{$\begin{array}{l}\text { Depression is a mood disorder characterized by the presence of sad, empty or } \\
\text { irritable feelings accompanied by somatic and cognitive changes that significantly } \\
\text { affect the individual's capacity to function. Depression affects an individual's } \\
\text { daily living activities such as work, sleeping, eating and concentration on the } \\
\text { tasks. The present study was conducted on } 500 \text { adolescents i.e., } 250 \text { adolescents } \\
\text { from urban area and } 250 \text { adolescents from rural area studying in } 10^{\text {th }}, 11^{\text {th }} \text { and } 12^{\text {th }} \\
\text { classes. Children Depression Inventory (CDI) developed by Kovacs }(2003) \text { was } \\
\text { used to measure the depression among adolescents. Results revealed that urban } \\
\text { adolescents were facing the problem of depression at higher level as compared to } \\
\text { rural adolescents, adolescents who had } 1^{\text {st }} \text { ordinal position among their siblings, } \\
\text { had problem of ineffectiveness; those having } 3 \text { to } 4 \text { siblings, had higher negative } \\
\text { mood and negative self - esteem and the adolescents who had no land, had higher } \\
\text { negative self - esteem which indicate that they require intervention for coming out } \\
\text { from depression symptoms. }\end{array}$} \\
\hline Ar & \\
\hline $\begin{array}{l}\text { Accepted: } \\
24 \text { August } \\
\text { Available } \\
10 \text { Septemb }\end{array}$ & \\
\hline
\end{tabular}

\section{Introduction}

Adolescence, a sensitive period marked with events such as puberty and identity crisis, on its own, can play a significant role in the development of an individual's selfperception. Adolescence marks a period of not only dramatic hormonal and biological maturation, but social and identity manifestations tend to occur as well. Adjustment during adolescence can be challenging and unpredictable (Elalky et al., 2015).
Depression is a mood disorder characterized by the presence of sad, empty or irritable feelings accompanied by somatic and cognitive changes that significantly affect the individual's capacity to function. Depression affects a human's daily living activities such as work, sleeping, eating and concentration on the tasks. People with depression may avoid any social contacts and some of them may have thoughts of death or suicide. Studies illustrate the increase in aggressiveness, depression and suicidal cases among adolescents (American Psychiatric 
Association, 2013). Prabhakar and Dubouis (2013) revealed that in India about 5\% people are living with depression, anxiety disorders and other psychological problems whereas, there are only about 4,000 psychiatrists, 1,000 psychologists and 3,000 social workers for the whole of the country.

According to Gupta and Basak (2013), a substantial number of adolescents in the general population suffer from depression with rates ranging from $4 \%$ to $20 \%$. Thus, depression among adolescents has emerged as a major mental health problem in recent years in India.

The present study was, therefore, undertaken to find out the extent of depression among adolescents in Haryana and to judge the effect of socio-personal variables on depression level of adolescents.

\section{Materials and Methods}

\section{Procedure and Place}

As per the technical programme, adolescents studying in $10^{\text {th }}, 11^{\text {th }}$ and $12^{\text {th }}$ standard from the selected schools from rural as well as from urban area were included in study to represent the sample. To represent the rural sample, two villages namely Arya Nagar and Behbalpur were randomly selected and for urban sample, Government senior secondary schools of Patel Nagar and Satrod from Hisar city were selected. From each selected school, 125 adolescents were taken to represent the sample.

\section{Participants}

Adolescents studying in $10^{\text {th }}, 11^{\text {th }}$ and $12^{\text {th }}$ classes including boys and girls were selected to represent the sample. In total 500 adolescents i.e., 250 each from urban and rural area constituted the study sample.

\section{Tools used}

Children Depression Inventory (CDI) developed by Kovacs (2003) was used to measure the depression level of adolescents.

\section{Statistical analysis}

SPSS Programme was run to analyze the data. Independent sample t- test and One - Way ANOVA were used to examine the depression among adolescents.

\section{Results and Discussion}

\section{Personal profile of adolescents across residential area}

Personal profile provides the information with regard to rural and urban adolescents with personal variables. Personal profile of adolescents in table 1 envisages that majority of the respondents $(63 \%)$ fall in the age group of $15^{+}-17$ years, followed by 56.8 per cent of adolescents from rural area and 69.2 per cent of adolescents from urban area.

Regarding gender wise distribution of the sample, results highlighted that more than half $(53.4 \%)$ respondents were males and rest of the respondents $(46.6 \%)$ were females.

Turning towards ordinal position, it was seen that 33.6 per cent of adolescents from total sample were first born among their siblings. Residential area wise distribution clearly shows that 38 per cent of adolescents from urban area were first born whereas 34 per cent of adolescents from rural area were second born among their siblings.

Results further shows that adolescents from urban area were good academic achievers $(86.4 \%)$ as compared to adolescents from urban area $(63.2 \%)$. 


\section{Depression status of adolescents across residential area}

Table 2 displays the residential area wise depression status of adolescents. In this section, the categories have been formed against the norms. The categories slightly above average and much above average describe the person having different degrees of depression and indicate the requirement of clinical attention/intervention. Residential area wise comparison showed that urban adolescents reported higher percentage (24\%) of having negative mood as compared to rural adolescents (16\%). Results highlighted that rural adolescents had more interpersonal problems $(24.4 \%)$ than urban adolescents $(20.8 \%)$ at much above average level. Problem of ineffectiveness was shown by 36.4 percent adolescents at average level. On the basis of residential area, results displayed that urban adolescents (11.2\%) showed the feelings of ineffectiveness at much above average level more than rural adolescents $(8.8 \%)$.

Turning towards anhedonia, a higher percentage of urban adolescents $(18.8 \%)$ were facing the problem of anhedonia than rural adolescents (17.2\%). Moving towards negative self-esteem, more than half adolescents (64.2\%) from total sample reported having average level of negative self-esteem. 15.20 per cent of urban adolescents whereas 9.6 per cent of rural adolescents had much above average symptoms of negative self-esteem. For overall depression, it was seen that 14.8 per cent, 12.8 per cent and 13.8 per cent of urban adolescents, rural adolescents and adolescents from total sample respectively were at risk of having depression as they lie in the category of slightly above average.

On the whole, nearly 20 per cent of urban adolescents, 11.6 per cent of rural adolescents and 15.8 per cent of total sample were facing the problem of depression at higher level, which indicate that they require intervention for coming out from depression symptoms.

\section{Comparison of depression among adolescents across socio - personal variables}

Table 3 highlights the results of comparison of depression among adolescent across socio personal variables. Significant differences were observed in ineffectiveness across residential area $(Z=2.58)$ and ordinal position $(\mathrm{F}=2.55)$, in negative $\operatorname{mood}(\mathrm{F}=$ 2.70) and negative self - esteem $(F=2.14)$ across number of siblings of adolescents on $\mathrm{Z}$ -test and Duncan multiple difference comparison test. Significant differences were also observed in negative self - esteem ( $\mathrm{F}=$ 2.81) across land holding among adolescents at 0.05 level of significance.

Mean comparison predicted that adolescents residing in urban area $(\mathrm{M}=48.84)$ were more ineffective than the adolescents residing in rural area $(M=46.65)$. Further comparison results showed that adolescents who had $1^{\text {st }}$ ordinal position among their siblings, were facing the problem of ineffectiveness at higher level $(\mathrm{M}=49.26)$.

Mean score comparison further highlighted that adolescents who had 3 to 4 siblings reported higher negative mood $(\mathrm{M}=54.34)$ as well as higher level of negative self - esteem $(\mathrm{M}=51.21)$ as compared to adolescents having 1 to 2 siblings and 5 and above siblings. Mean score comparison also revealed that adolescents who had no land, had higher negative self - esteem $(M=51.26)$ as compared to the adolescents who had land up to 1 acre $(\mathrm{M}=50.42), 1^{+}-2$ acre $(\mathrm{M}=$ 48.68), $2^{+}-10$ acre $(M=47.71)$ and $>10$ acre $(\mathrm{M}=46.88)$. 
Table.1 Personal profile of adolescents across residential area

\begin{tabular}{|c|c|c|c|c|}
\hline S.No . & $\begin{array}{l}\text { Residential area } \\
\text { Personal variables }\end{array}$ & $\begin{array}{c}\text { Rural } \\
(\mathbf{n}=\mathbf{2 5 0})\end{array}$ & $\begin{array}{c}\text { Urban } \\
(\mathbf{n}=250)\end{array}$ & $\begin{array}{c}\text { Total } \\
(\mathbf{n}=\mathbf{5 0 0})\end{array}$ \\
\hline \multirow[t]{4}{*}{1.} & Adolescent's age & & & \\
\hline & $14-15^{+}$years & $63(25.20)$ & $57(22.80)$ & $120(24.00)$ \\
\hline & $16-17^{+}$years & $142(56.80)$ & $173(69.20)$ & $315(63.00)$ \\
\hline & $18-19^{+}$years & $45(18.00)$ & $20(08.00)$ & $65(13.00)$ \\
\hline \multirow[t]{3}{*}{2.} & Sex & & & \\
\hline & Male & $126(50.40)$ & $141(56.40)$ & $267(53.40)$ \\
\hline & Female & $124(49.60)$ & $109(43.60)$ & $233(46.60)$ \\
\hline \multirow[t]{5}{*}{3.} & Ordinal position & & & \\
\hline & $1^{\text {st }}$ born & $73(29.20)$ & $95(38.00)$ & $168(33.60)$ \\
\hline & $2^{\text {nd }}$ born & $85(34.00)$ & $76(30.40)$ & $161(32.20)$ \\
\hline & Up to $4^{\text {th }}$ born & $71(28.40)$ & $71(28.40)$ & $142(28.40)$ \\
\hline & $>4^{\text {th }}$ born & $21(08.40)$ & $08(03.20)$ & $29(05.80)$ \\
\hline \multirow[t]{4}{*}{4.} & Academic achievement & & & \\
\hline & Poor $(33 \%-50 \%)$ & $23(09.20)$ & 03(01.20) & $26(05.20)$ \\
\hline & Average $(>50 \%-60 \%)$ & $69(27.60)$ & $31(12.40)$ & $100(20.00)$ \\
\hline & Good $(>60 \%)$ & $158(63.20)$ & $216(86.40)$ & $374(74.80)$ \\
\hline \multirow[t]{4}{*}{5.} & Academic class & & & \\
\hline & $10^{\text {th }}$ & $81(32.40)$ & $40(16.00)$ & $121(24.20)$ \\
\hline & $11^{\text {th }}$ & $87(34.80)$ & $130(52.00)$ & $217(43.40)$ \\
\hline & $12^{\text {th }}$ & $82(32.80)$ & $80(32.00)$ & $162(32.40)$ \\
\hline
\end{tabular}

Note: Figures in parentheses indicate percentages

Table.2 Depression status of adolescents across residential area

\begin{tabular}{|l|c|c|c|c|}
\hline \multirow{2}{*}{\begin{tabular}{|c|c|} 
Aspects of depression \\
\cline { 2 - 5 }
\end{tabular}} & $\begin{array}{c}\text { CDI T - } \\
\text { score }\end{array}$ & $\begin{array}{c}\text { Rural } \\
(\mathbf{n = 2 5 0})\end{array}$ & $\begin{array}{c}\text { Urban } \\
(\mathbf{n = 2 5 0})\end{array}$ & $\begin{array}{c}\text { Total } \\
(\mathbf{n = 5 0 0})\end{array}$ \\
\hline Negative mood & & & & \\
\hline Much below average & $35-39$ & $10(04.00)$ & $12(04.80)$ & $22(04.40)$ \\
\hline Slightly below average & $40-44$ & $44(17.60)$ & $33(13.20)$ & $77(15.40)$ \\
\hline Average & $45-55$ & $120(48.00)$ & $96(38.40)$ & $216(43.20)$ \\
\hline Slightly above average & $56-60$ & $36(14.40)$ & $49(19.60)$ & $85(17.00)$ \\
\hline Much above average & 61 and above & $40(16.00)$ & $60(24.00)$ & $100(20.00)$ \\
\hline Interpersonal problems & & & & \\
\hline Much below average & $35-39$ & - & - & - \\
\hline Slightly below average & $40-44$ & $96(38.40)$ & $104(41.60)$ & $200(40.00)$ \\
\hline Average & $45-55$ & $68(27.20)$ & $67(26.80)$ & $135(27.00)$ \\
\hline Slightly above average & $56-60$ & $25(10.00)$ & $27(10.80)$ & $52(10.40)$ \\
\hline Much above average & 61 and above & $61(24.40)$ & $52(20.80)$ & $113(22.60)$ \\
\hline Ineffectiveness & & & & \\
\hline
\end{tabular}




\begin{tabular}{|l|c|c|c|c|}
\hline Much below average & $35-39$ & $82(32.80)$ & $69(27.60)$ & $151(30.20)$ \\
\hline Slightly below average & $40-44$ & $35(14.00)$ & $24(09.60)$ & $59(11.80)$ \\
\hline Average & $45-55$ & $90(36.00)$ & $92(36.80)$ & $182(36.40)$ \\
\hline Slightly above average & $56-60$ & $21(08.40)$ & $37(14.80)$ & $58(11.60)$ \\
\hline Much above average & 61 and above & $22(08.80)$ & $28(11.20)$ & $50(10.00)$ \\
\hline Anhedonia & & & & \\
\hline Much below average & $35-39$ & $08(03.20)$ & $17(06.80)$ & $25(05.00)$ \\
\hline Slightly below average & $40-44$ & $28(11.20)$ & $38(15.20)$ & $66(13.20)$ \\
\hline Average & $45-55$ & $123(49.20)$ & $99(39.60)$ & $222(44.40)$ \\
\hline Slightly above average & $56-60$ & $48(19.20)$ & $49(19.60)$ & $97(19.40)$ \\
\hline Much above average & 61 and above & $43(17.20)$ & $47(18.80)$ & $90(18.00)$ \\
\hline Negative self - esteem & & & & \\
\hline Much below average & $35-39$ & $20(08.00)$ & $18(07.20)$ & $38(07.60)$ \\
\hline Slightly below average & $40-44$ & $13(05.20)$ & $25(10.00)$ & $38(07.60)$ \\
\hline Average & $45-55$ & $175(70.00)$ & $146(58.40)$ & $321(64.20)$ \\
\hline Slightly above average & $56-60$ & $18(07.20)$ & $23(09.20)$ & $41(08.20)$ \\
\hline Much above average & 61 and above & $24(09.60)$ & $38(15.20)$ & $62(12.40)$ \\
\hline Overall depression & & & & \\
\hline Much below average & $35-39$ & $06(02.40)$ & $10(04.00)$ & $16(03.20)$ \\
\hline Slightly below average & $40-44$ & $26(10.40)$ & $39(15.60)$ & $65(13.00)$ \\
\hline Average & $45-55$ & $157(62.80)$ & $114(45.60)$ & $271(54.20)$ \\
\hline Slightly above average & $56-60$ & $32(12.80)$ & $37(14.80)$ & $69(13.80)$ \\
\hline Much above average & 61 and above & $29(11.60)$ & $50(20.00)$ & $79(15.80)$ \\
\hline
\end{tabular}

Note: Figures in parentheses indicate percentages

Table.3 Comparison of depression among adolescents across personal variables ( $\mathrm{N}=500)$

\begin{tabular}{|c|c|c|c|c|c|c|}
\hline \multirow[b]{3}{*}{$\begin{array}{l}\text { Aspects of } \\
\text { depression }\end{array}$} & \multicolumn{6}{|c|}{ Personal variables } \\
\hline & \multicolumn{6}{|c|}{ Residential area } \\
\hline & \multicolumn{2}{|c|}{$\begin{array}{c}\text { Rural } \\
\text { Mean } \pm \text { SD }\end{array}$} & \multicolumn{2}{|c|}{$\begin{array}{c}\text { Urban } \\
\text { Mean } \pm \text { SD }\end{array}$} & \multicolumn{2}{|c|}{$Z$ value } \\
\hline Negative mood & \multicolumn{2}{|c|}{$53.23 \pm 08.89$} & \multicolumn{2}{|c|}{$54.77 \pm 09.77$} & \multicolumn{2}{|c|}{1.84} \\
\hline $\begin{array}{l}\text { Interpersonal } \\
\text { problems }\end{array}$ & \multicolumn{2}{|c|}{$53.07 \pm 10.15$} & \multicolumn{2}{|c|}{$52.34 \pm 09.97$} & \multicolumn{2}{|c|}{0.81} \\
\hline Ineffectiveness & \multicolumn{2}{|c|}{$46.65 \pm 09.14$} & \multicolumn{2}{|c|}{$48.84 \pm 09.97$} & \multicolumn{2}{|c|}{$2.58^{*}$} \\
\hline Anhedonia & \multicolumn{2}{|c|}{$53.35 \pm 08.42$} & \multicolumn{2}{|c|}{$52.76 \pm 09.71$} & \multicolumn{2}{|c|}{0.72} \\
\hline $\begin{array}{l}\text { Negative } \quad \text { self- } \\
\text { esteem }\end{array}$ & \multicolumn{2}{|c|}{$49.82 \pm 08.23$} & \multicolumn{2}{|c|}{$50.97 \pm 09.46$} & \multicolumn{2}{|c|}{1.45} \\
\hline \multirow[t]{3}{*}{ Overall depression } & \multicolumn{2}{|c|}{$52.00 \pm 07.89$} & \multicolumn{2}{|c|}{$52.89 \pm 09.40$} & \multicolumn{2}{|c|}{1.14} \\
\hline & \multicolumn{6}{|c|}{ Ordinal position } \\
\hline & $\begin{array}{c}1^{\text {st }} \text { born } \\
\text { Mean } \pm \text { SD }\end{array}$ & $\begin{array}{c}\mathbf{2}^{\text {nd }} \text { born } \\
\text { Mean } \pm \text { SD }\end{array}$ & $\begin{array}{c}3^{\text {rd }} \text { born } \\
\text { Mean } \pm \text { SD }\end{array}$ & $\begin{array}{c}4^{\text {th }} \text { born } \\
\text { Mean } \pm \text { SD }\end{array}$ & $\begin{array}{c}5^{\text {th }} \text { born } \\
\text { and above } \\
\text { Mean } \pm \text { SD }\end{array}$ & $\begin{array}{c}F \\
\text { value }\end{array}$ \\
\hline Negative mood & $54.32 \pm 09.97$ & $54.81 \pm 10.15$ & $53.20 \pm 08.65$ & $53.94 \pm 06.26$ & $50.57 \pm 05.82$ & 1.48 \\
\hline
\end{tabular}




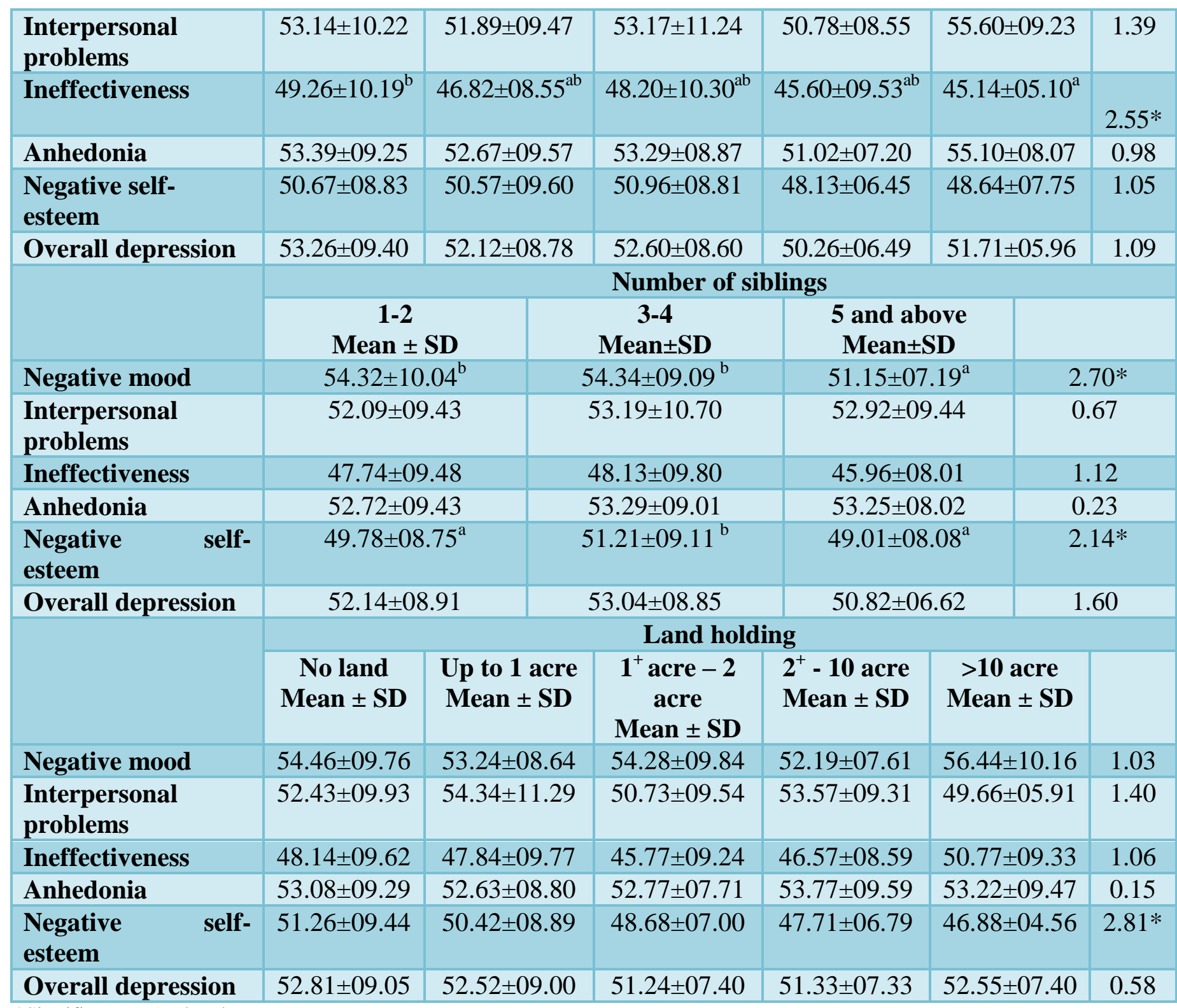

*Significant at $5 \%$ level

Note: Means in the same row that do not share superscripts differ at $\mathrm{p}<0.05$ using Duncan multiple difference comparison

Current study revealed that adolescents in Haryana suffered from mild to severe depression. Malik et al., (2015) conducted a similar study in Haryana among $9^{\text {th }}$ and $10^{\text {th }}$ grade students and stated that nearly one out of seven was suffering from moderate to severe depression. In the present investigation, urban adolescents reported higher negative mood, interpersonal problems, feelings of ineffectiveness, anhedonia, negative self - esteem and overall depression as compared to rural adolescents. It may be due to lack of social - support in urban areas, nuclear family structure, absence of elder brother or sister in case of single child family and higher academic competitiveness. Because of that these adolescents cannot express themselves in front of others which directly invite the depressive symptoms in themselves. Jayashree et al., (2018) and Li et al., (2019) also found that urban adolescents were more 
depressed as compared to rural adolescents. Another finding by Ajaero et al., (2018) also revealed that urban adolescents were more depressed than their rural counterparts.

Further it was found that adolescents, who had $1^{\text {st }}$ ordinal position among their siblings, were facing the problem of ineffectiveness at higher level. The reason behind this may be that adolescents who have $1^{\text {st }}$ ordinal position among the siblings are under family pressure to behave and act properly in front of their siblings so that their life becomes exemplary to their younger brothers and sisters. Also, another reason could be absence of an elder brother's or sister's support and guidance. Easey et al., (2019) also found that ordinal position can be a predictor of depression among adolescents.

Mean score comparison further highlighted that adolescents, who had fewer number of siblings reported higher negative mood as well as higher level of negative self - esteem. It can be logically presumed that due to lesser number of siblings means lesser support from the siblings. Due to fewer numbers of siblings, they cannot even discuss their problems or express their thoughts with their age mates in the family.

Results also revealed that adolescents, who had no land, had higher negative self esteem. Possession of land is a status symbols in the society therefore those adolescents who do not have land lacked confidence among their peer group. This lack in confidence give rise to low self - esteem, self - dislike and feeling of being unimportant in the peergroup, which ultimately leads to depression.

It can be concluded that urban adolescents were facing the problem of depression at higher level as compared to rural adolescents; adolescents who had $1^{\text {st }}$ ordinal position among their siblings, had problem of ineffectiveness; adolescents having one to two siblings had higher negative mood and negative self - esteem and the adolescents who had no land, had higher negative self esteem which indicate that they require intervention for coming out from depression symptoms.

\section{Acknowledgement}

We would like to thank all researchers, participants and staff of the schools for their support and effort in this study.

\section{References}

Ajaero, C., Nzeadibe, C. and gboeli, E. E. 2018. Rural-urban differences in the prevalence and predictors of depression among adolescents in South Africa. South African journal of child health. 12: 71-74.

American Psychiatric Association. 2013. Diagnostic and statistical manual of mental disorders (5th edition). Arlington.

Easey, K. E., Mars, B., Pearson, R., Heron, J. and Gunnell, D. 2019. Association of birth order with adolescent mental health and suicide attempts: a population-based longitudinal study. European Child and Adolescent Psychiatry. 28: 1079-1086.

Elalky, M. I., Othman, Z. A. E., Eita, L. H., Eldemerdash, K. I. 2015. The effect of birth order and socio demographic characteristics on anxiety and depression among adolescents. International Journal of Nursing Science. 5(3): 110121.

Gupta, S. and Basak, P. 2013. Depression and type D personality among undergraduate medical students. Indian Journal of Psychiatry. 55(3): 287-289.

Jayashree, K., Mithra, P. P., Nair, M. K. C., Unnikrishnan. B. and Pai, K. 2018. 
Depression and anxiety disorders among schoolgoing adolescents in an urban area of South India. Indian Journal of Community Medicine. 43 (5): 28-32.

Kovacs. M. 2003. Child Depression Inventory. Multi - Health Systems Inc. Canada.

Li, G., Mei, J., You, J., Miao, J., Song, X., Sun, W., Lan, Y., Qiu, X. and Zhu, Z. 2019. Sociodemographic characteristics associated with adolescent depression in urban and rural areas of Hubei province: a cross-sectional analysis. BMC Psychiatry. 19: 386.
Malik, M., Khanna, P., Rohilla, R., Mehta, B. and Goyal, A. 2015. Prevalence of depression among school going adolescents in an urban area of Haryana, India. International Journal of Community Medicine and Public Health, 2(4): 624-626.

Prabhakar, A. and Dubouis, K. 2013. A national survey on mental health disorders in India. Retrieved from: http: // www.dnaindia.com/health/report finally, national-survey -on -mentalhealth-disorders-in -India 1848694.

\section{How to cite this article:}

Rupika Chopra and Sheela Sangwan. 2020. Differences in Depression Level among Rural and Urban Adolescents of Haryana, India. Int.J.Curr.Microbiol.App.Sci. 9(09): 3391-3398. doi: https://doi.org/10.20546/ijcmas.2020.909.421 